\title{
KSIĘGOZBIÓR PARAFII WE WRZAWACH W ŚWIETLE WIZYTACJI GENERALNEJ Z 1748 ROKU
}

Parafia p.w. Najświętszej Maryi Panny Królowej Polski we Wrzawach była w ostatnim czasie przedmiotem badań historyków: Benedykta Budziły oraz Waldemara Prarata ${ }^{2}$. W opinii uznanych badaczy dziejów Kościoła (ks. Bolesława Kumora, Waldemara Kowalskiego) czas jej erygowania przypada na XIII w.3. Podawana jest data I27I r. Przed laty Józef Rawski pisał na ten temat: „Fundacja prywatna rodu Dębno, który według [W.] Semkowicza posiadał klucz warszawski. Parafia Wrzawy powstała z części parafii Gorzyce, obejmującej osady leżące po wschodnim brzegu Sanu, miedzy Wisłą i Sanem, oraz w górę Sanu po Żabno włącznie. San w tych czasach wpadał do Wisły między Gorzycami a Wrzawami, pozostawiając te ostatnie po wschodnim brzegu. Akt wizytacyjny z roku I793 podaje, że parafia Wrzawy powstała w roku I27I"4.

Do końca XV w. parafia wrzawska należała terytorialnie do archidiakonatu sandomierskiego w diecezji krakowskiej5. Następnie włączono ją do archidiakonatu zawichojskiego, który w początkach XVII w. został podzielony na 3 dekanaty: Opatów, Urzędów, Zawichost ${ }^{6}$. Parafia wrzawska znalazła się w granicach dekanatu urzędowskiego, w którym funkcjonowała do roku $1772^{7}$.

\footnotetext{
* Ks. dr hab. Tomasz Moskal, prof. KUL, Katedra Historii Kościoła w Czasach Najnowszych, Metodologii i Nauk Pomocniczych w Instytucie Historii Kościoła i Patrologii, Katolicki Uniwersytet Lubelski Jana Pawła II, adres do korespondencji: tomos@kul.pl.

1 B. Budziło, Gorzyce i Wrzawy. Zarys dziejów, Kraków 2000; tenże, Wrzawy w świetle kronik, pamiętników i relacji, Wrzawy-Sandomierz 2008.

2 W. Prarat, Wrzawy. Szkice z dziejów wsi, Wrzawy-Sandomierz 2001; tenże, Parafia Wrzawy. Zarys dziejów, Wrzawy-Sandomierz 2008.

3 B. Kumor, Dzieje diecezji krakowskiej do roku 1795, t. 4, Kraków 2002, s. 200; W. Kowalski, Uposażenie parafi archidiakonatu sandomierskiego w XV-XVIII wieku, Kielce 1998, s. 357.

4 J. Rawski, Wybrane zagadnienia dotyczace administracji kościelnej w widłach Wisly i Sanu, Tarnobrzeg 1997, s. 31 .

5 W. Kowalski, Uposażenie parafii..., s. 357.

6 B. Kumor, Dzieje diecezji krakowskiej..., s. 54.

7 Na dekanat urzędowski składały się wówczas następujące parafie: Batorz, Biała, Borów, Dzierzkowice, Goraj, Gościeradów, Kraśnik, Modliborzyce, Pniów, Popkowice, Potok Wielki, Prawno, Radomyśl, Radzięcin, Rybitwy, Świeciechów, Targowisko, Urzędów, Wrzawy, Wysokie, Zaklików, zob. S. Litak, Kościót łaciński w Rzeczypospolitej około 1772 roku. Struktury administracyjne, Lublin 1996, s. 258-259. Dość wspomnieć, że 23 X 1773 r. biskup krakowski Kajetan Ignacy Sołtyk przeprowadził reorganizację sieci dekanalnej, skutkiem czego było m.in. włączenie parafii Wrzawy do dekanatu rudnickiego, zob. J. Szczepaniak, Duchowieństwo diecezji krakowskiej w XVIII wieku. Studium prozopograficzne, Kraków 2010, s. 38.
} 
W I748 r. parafię we Wrzawach zwizytował z polecenia biskupa krakowskiego Andrzeja Stanisława Załuskiego (I695-I758) ${ }^{8}$ archidiakon zawichojski, Cyprian Józef Lange $(+\mathrm{I} 757)^{9}$. Księga zawierająca protokół powizytacyjny przechowywana jest w Archiwum Kurii Metropolitalnej w Krakowie ${ }^{10}$. Wynika z niego m.in., że parafia posiadała drewniany kościół, zaś od I747 r. proboszczem był ks. Antoni Hadziewicz ${ }^{\text {II }}$. Protokół powizytacyjny informuje także o istnieniu księgozbioru parafialnego, który został zapisany pod tytułem In libris. Wyliczonych zostało I5 książek. Twórca protokołu zapisał je, używając głównie imienia lub nazwiska autora i krótkiego fragmentu tytułu ${ }^{12}$. Ze spisu wynika, że I2 książek zostało opublikowanych w języku łacińskim, a tylko 3 po polsku. Większość tytułów jest możliwa do zidentyfikowania. W odniesieniu do niektórych zapisów ich wieloznaczność sprawia, że badacz pozostaje w sferze domysłów. Trudno bowiem trafnie określić, które wydanie tekstu Pisma Świętego kryło się za określeniem Biblia sacra czy też Pars Bibliarum. Również zapis Kazania panegiryczne może kryć wiele różnych tytułów. By jednak ukazać trudności związane z identyfikacją tak zapisanych dzieł, autor niniejszego opracowania podał w przypisach wybrane, najpopularniejsze bądź najbardziej znane publikacje, zabierające w tytule określenie użyte w inwentarzu. Analizując zawartość księgozbioru pod kątem użyteczności parafialnej, bez wątpienia można go określić jako duszpasterski. Księgi kaznodziejskie, teologicznomoralne i ascetyczne wymownie za tym przemawiają.

Na pierwszym miejscu w spisie została umieszczona Biblia. O ile, jak wyżej zostało to już zaznaczone, nie sposób jest określić, w jakim wydaniu, o tyle nie należy się dziwić jej obecności w księgozbiorze parafialnym we Wrzawach. Wszak stanowi źródło poznania treści objawionych. Była zapewne wykorzystywana tak w prywatnej lekturze duszpasterza, jak i w codziennej praktyce pracy parafialnej. Należy nadto zauważyć również obecność jej innego wydania. Tak bowiem należałoby tłumaczyć zapis „Pars Bibliarum”. Czy był to tylko Stary lub Nowy Testament? Czy może wolumin zawierający wybrane księgi? Niestety, nie jest możliwe rozstrzygniecie tej kwestii. Trudno także mówić o szczególnym zainteresowaniu Pismem Świętym duszpasterzy we Wrzawach, aczkolwiek i tego nie można wykluczyć.

Po tekście Pisma Świętego niezwykle ważnym, biorąc pod uwagę praktykę codziennej a już na pewno niedzielnej i świątecznej pracy duszpasterskiej, były zbiory kazań. W księgozbiorze wrzawskim można dokonać swoistego podziału na książki homiletyczne

\footnotetext{
8 Biskup płocki, łucki, chełmiński, administrator apostolski diecezji pomezańskiej, od 1746 roku krakowski, zob. P. Nitecki, Biskupi Kościoła w Polsce w latach 965-1999. Stownik biograficzny, Warszawa 2000, kol. 506.

9 Doktor obojga praw, archidiakon zawichojski, kanonik krakowski, sandomierski, wiślicki, prepozyt w Rakowie, zob. J. Wiśniewski, Katalog prałatów i kanoników sandomierskich od 1186 do 1929 r., tudzież sesje kapituły sandomierskiej od 1581 do 1866 r., Radom 1928, s. 175-176.

10 AKMK, sygn. AV 46, Archidiaconatus Zawichostensis, tres decanatus, videlicet Urzędoviensem, Opatoviensem et Zawichostensen, in quibus ecclesiae parochiales numerantur 45, complectens, sub felici regimine et auspiciis Cel. Principis R. D. Adreae Stanislai Kostka comitis in Załuskie Załuski, episcopi Cracoviensis, ducis Severiae, generali visitatione lustratus, per Cyprianum Joosephum Langi IUD, in ecclesia cathedrali Cracoviensi, archidiaconum Zawichostensem, canonicum Sandomieriensem, praepositum Rakoviensem anno 1748. Wykorzystałem mikrofilm wizytacji przechowywany w ABMK, sygn. 3317.

11 J. Szczepaniak, Spis prepozytów i plebanów diecezji krakowskiej (XVIII w.), Kraków 2008, s. 366; tenże, Katalog duchowieństwa diecezjalnego zestawiony na podstawie krakowskich ksiąg święceń (1646-1789), A-I, Kraków 2008, s. 353.

$12 \mathrm{Na}$ temat zapisu księgozbiorów w protokołach powizytacyjnych pisali m.in. T. Moskal, Biblioteki parafialne $w$ archidiakonacie sandomierskim $w$ XVIII wieku, Sandomierz 2005, s. 78-83; J. Szady, Księgozbiory parafialne w prepozyturze wiślickiej w II połowie XVIII wieku, Lublin 2008, s. 53-58.
} 
wydrukowane w języku polskim i łacińskim. W związku z tym, że w tej grupie są wszystkie 3 polonica kaznodziejskie, one zostaną omówione w pierwszej kolejności.

Jako numer 2 w spisie książek zapisane zostały Kazania Lorencowicza. Odnosi się to z pewnością do osoby jezuity Aleksandra Lorencowicza (I605-I672). Był jednym z najwybitniejszym kaznodziejów epoki baroku. Pełniąc w zakonie wiele funkcji (m.in. rektor kolegium we Lwowie I656-I659, I672-I674 oraz Jarosławiu I66I-I664, prowincjał jezuitów I668-I67I, prokurator do sprawy kanonizacji bł. Stanisława Kostki), był także kaznodzieją w Krakowie

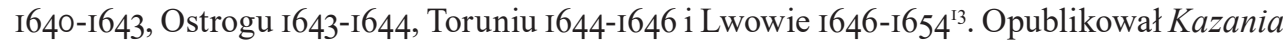
pogrzebne miane w różnych żałobnych okazjach wydane w I670 r. w Kaliszu oraz rok później tamże Kazania na niedziele całego roku. W pierwszej publikacji, składającej się z 28 tekstów homilii pogrzebowych, autor dokonał podziału kazań na uroczystości funeralne mężczyzn (I9) i kobiet (9) oraz stanowe (m.in. Na wyprowadzenie ciała panięcia młodego od Tatarów okrutnie zabitego lub Na pogrzebie szlachcica, który bywszy heretykiem namówionym znowu do wiary prawdziwej się wrócił). Jak wskazuje M. Krzysztofik, „Cechę charakterystyczną całego zbioru stanowią wyjątkowo liczne i różnorodne odwołania do Biblii, na co wpłynęło niewątpliwie jezuickie wykształcenie autora oraz reguła zakonna"I4. Z kolei jego Kazania na niedziele całego roku wydane w dwóch częściach w Kaliszu w i67I r., ukazują Lorencowicza jako kaznodzieję, który doskonale zrozumiał zadanie mówcy na ambonie. Jako bezkompromisowy szermierz słowa Bożego w 63 mowach ,widzi jasno ujemne strony społeczeństwa i przy każdej sposobności karci surowo nadużycia szlachty i mieszczan, do których przeważnie przemawiał"' ${ }^{5}$. Co ciekawe, kaznodzieja miał świadomość swojej nieprzejednanej postawy, gdyż sam siebie nierzadko porównywał do trąby strasznej ${ }^{\mathrm{j}}$.

Polską myśl homiletyczną reprezentował w księgozbiorze parafialnym we Wrzawach również Sebastian Stryjewicz (I62I-I68I) ${ }^{17}$. Ten wybitny teolog, profesor Uniwersytetu Krakowskiego, kanonik kolegiaty p.w. św. Floriana na Kleparzu, opublikował w Krakowie w I680 r. Kazania na święta uroczyste Pana Zbawiciela Naszego, Najświętszej Panny Mariej $i$ Świętych Pańskich... Był to zbiór 69 homilii, które wygłosił w różnych okresach swojego życia. Skupiał się w nich przede wszystkim na żarliwości w wierze oraz szacunku dla duszpasterzy. Starał się omijać, a jeśli już pisał, to rzadko i ogólnikowo, tematy etyczne. Pomijał również zagadnienia społeczno-polityczne ${ }^{\mathrm{I} 8}$.

Zapis „Kazania panegiryczne” jest bardzo wieloznaczny. Wśród publikacji, które zawierają w tytule to określenie, a przydatnych w pracy parafialnej, mogą kryć się np. Panegiryczne niektóre dyskursy duchowne i różne insze kazania, przy celniejszym i obfitszym audytorze, w kościołach zwłaszcza krakowskich pewnych czasów miane. Ich autorem jest

13 K. Panuś, Lorencowicz Aleksander, w: Encyklopedia Katolicka, t. 10, red. E. Ziemann, Lublin 2004, kol. 1396.

14 M. Krzysztofik, Biblia w kazaniach pogrzebnych Aleksandra Lorencowicza (1670) - płaszczyzna obecności, funkcje nawiązania, „Zeszyty Naukowe Uniwersytetu Rzeszowskiego”, Seria Filologiczna, Zeszyt 65/2010, Historia literatury 5, s. 64-65. Zob. także tej samej autorki Siedemnastowieczna refleksja o rolach kobiety i mężczyzny w matżństwie (na podstawie kazań pogrzebowych), „Res gestae. Czasopismo historyczne”, 2016, nr 3, s. 6-7.

15 J. Sas, Aleksander Lorencowicz. Studium z epoki panegirycznej, „Przegląd Powszechny”, 39/1893, s. 85.

16 K. Panuś, Zarys historii kaznodziejstwa w Kościele katolickim, t. 2, cz. 1: Kaznodziejstwo w Polsce. Od Średniowiecza do Baroku, Kraków 2001, s. 454.

17 E. Ozorowski, Stryjewicz Sebastian Fabian, w: Słownik Polskich Teologów Katolickich, t. 4, red. H. E. Wyczawski, Warszawa 1983, s. 218-219.

18 M. Barcik, Sebastian Fabian Stryjewicz, w: Polski Słownik Biograficzny, t. 44, Kraków 2006-2007, s. 528-530. 
franciszkanin konwentualny Walerian Wojciech Gutowski (I629-I693) ${ }^{19}$, który opublikował je w Krakowie w I675 r. Znajduje się w nich dedykacja skierowana do biskupa krakowskiego Andrzeja Trzebickiego (I607-I679). W 30 kazaniach, naszpikowanych łacińskimi cytatami, franciszkanin piętnował zrywanie sejmów, brak posłuszeństwa królowi, konfederacje wojskowe, ucisk poddanych, niesprawiedliwość sędziów. Korzystał przy tym obficie z Pisma Świętego, ojców Kościoła, teologów średniowiecznych oraz współczesnych mu pisarzy²0.

Omówienie łacińskojęzycznych dzieł homiletycznych występujących w księgozbiorze wrzawskim w połowie XVIII w. należy rozpocząć od zapisanego pod numerem 7 zbioru kazań napisanych przez hiszpańskiego jezuitę Juana Osoriusa (I542-I594). Jest on autorem kilku prac egzegetycznych, jak również pięciu tomów homilii, w tym wskazanych w protokole powizytacyjnym, przeznaczonych na Wielki Post ${ }^{21}$. Z Półwyspu Iberyjskiego wywodził się również Didacus Nissenus $(+\mathrm{I} 656)^{22}$. Kazania tego hiszpańskiego bazylianina zostały opublikowane m.in. u Łukasza Kupisza w Krakowie w I650 r. pod tytułem Opera omnia in tres tomos digesta...23. Przeglądając spis librarii można pokusić się o stwierdzenie, że także za zapisem „Petri bussaei apercula” kryje się dzieło kaznodziejskie. Jego autorem byłby francuski pisarz Petrus Bessaeus (I567-I639). Zdobywszy staranne wykształcenie (uzyskał doktorat na Sorbonie), był kaznodzieją króla Ludwika XIII (I60I-I643) oraz kapelanem księcia Henryka de Bourbon (I553-I6Io), późniejszego króla Francji ${ }^{24}$.

Do dzieł teologicznych, które posiadała parafia wrzawska, pod numerem 3 sekretarz wpisał „Meditationes Buscvi”. Z pewnością kryje się za tym postać Jana Busaeusa (I547-I6II), jezuity, pisarza ascetycznego, polemicznego, wydawcy i tłumacza tekstów teologicznych. Jego najpopularniejszym dziełem jest Enchiridion piarum meditationum in Dominicas ac festa totius anni. Nec non quadragesimae, quatuor-temporum, aliasque praecipuas ferias... W księgozbiorze we Wrzawach być może w wydaniu gdańskim z I700 r. Autor zawarł w nim propozycje I3 medytacji, m.in. na wszystkie niedziele roku; na uroczystości świętych; o Męce Pańskiej; o życiu Jezusa Chrystusa; o świętych: o apostołach, o męczennikach, o wyznawcach i dziewicach; o Bożych dobrach; o grzechach; o tajemnicach życia ludzkiego; o nowym człowieku; o Eucharystii; o godności kapłaństwa; o religijności; o piętnastu tajemnicach różańca.

Niesłabnącą popularnością do dnia dzisiejszego cieszy się tytuł sygnowany autorem „Thomas a Kempis" zapisany pod numerem Io. Autorstwo De imitatione Christi (O naśladowaniu Chrystusa) jest przypisywane kanonikowi regularnemu Tomaszowi a Kempis (I380-I47I) ${ }^{25}$.

\footnotetext{
19 E. Ozorowski, Gutowski Walerian Wojciech, w: Słownik Polskich Pisarzy Franciszkańskich, red. H. E. Wyczawski, Warszawa 1981, s. 168-169; A. Szteinke, Gutowski Bernard, w: Słownik Polskich Teologów Katolickich, t. 1, s. 611-612; A. Zwiercan, Gutowski Wojciech, w: Encyklopedia Katolicka, t. 6, red. J. Walkusz, Lublin 1993, kol. 410. O twórczości o. Waleriana Gutowskiego pisał W. Pawlak, Praedicator urbanus - Walerian Gutowski OFMConv., w: Wielcy kaznodzieje Krakowa. Studia in honorem prof. Eduardi Staniek, Kraków 2006, s. 191-226.

20 K. Panuś, Zarys historii kaznodziejstwa, s. 456; W. Pawlak, ,, O pewnym sposobie naszych literatów, że przy niewielkim czytaniu moga się łatwo wielkimi erudytami pokazać” Kompendia jako źródło erudycji humanistycznej, w: Staropolskie kompendia wiedzy, red. I. M. Dacka-Górzyńska, J. Partyka, Warszawa 2009, s. 55.

${ }^{21}$ M. Czapnik, Księgozbiór ks. Jana Bogusławskiego świadectwem zainteresowań cysterskiego kaznodziei i tlumacza, „Roczniki Biblioteczne”, 53/2009, s. 156.

22 A. Szudrowicz, Biblioteka klasztoru karmelitów w Kcyni, „Archiwa Biblioteki i Muzea Kościelne”, 78/2002, s. 257.

23 Estreicher K., Bibliografia polska, cz. 3, Kraków 1891-1951, t. 23, s. 159-160.

24 Besse Piotr, w: Podręczna Encyklopedia Kościelna, t. 1-2, red. Z. Chełmicki, Warszawa 1904, s. 279.

25 R. Prejs, Tomasz a Kempis, w: Encyklopedia Katolicka, t. 19, red. E. Gigilewicz, Lublin 2013, kol. 870-871.
} 
W tym dziele ascetycznym, które powstało ok. I427 r., znalazły odzwierciedlenie poglądy i duchowość devotio moderna ${ }^{26}$. O ponadczasowej wartości książeczki może świadczyć fakt, że była tłumaczona na wiele języków i wielokrotnie wznawiana ${ }^{27}$. Warto przytoczyć w tym miejscu opinię, którą na jej temat wyraził francuski autor opracowań z zakresu duchowości Pierre Pourrat: „Ułożone przez zakonników dla zakonników, pozostanie bez obawy zestarzenia się książką karmiącą pobożność wszystkich pokoleń" ${ }^{28}$.

W księgozbiorze wrzawskim znajduje się nadto pomniejsze dzieło ascetyczne kardynała z zakonu jezuitów Roberta Bellarmina (I542-I62I) noszące tytuł De aeterna felicitate sanctorum, które zostało wydane po raz pierwszy w Rzymie w I6I6 r. ${ }^{29}$ Autor podzielił je na księgi traktujące o królestwie Bożym, o państwie Bożym, o domu Bożym, o raju, o przypowieściach. Po dziele jezuickiego teologa autor protokołu powizytacyjnego lapidarnie zapisał „Grantensis”. Wskazał w ten sposób na jedno z dzieł zmarłego w opinii świętości dominikanina Louisa de Sarria (I504-I588), który znany jest w literaturze jako Ludwik z Granady. Jest on autorem Conciones de tempore, opublikowanych w 4 tomach w Lizbonie w latach I574-I576, oraz tamże Conciones de sanctis w 2 tomach w 1578 r $3^{30}$. Wśród innych jego dzieł na szczególną uwagę zasługują O modlitwie i rozmyślaniu opublikowane w Salamance w 554 r. oraz Przewodnik grzeszników czyli nauka dla wszystkich stanów o zacności i pożytkach cnót - dwutomowe wydanie zostało po raz pierwszy opublikowane w Lizbonie w latach $1556-57^{31}$. Są one zaliczane do klasyki literatury duchowej. Pierwsza publikacja odniosła niesłychany sukces wydawniczy, gdyż doczekała się ponad 200 wydań w Hiszpanii. Odwoływali się do niej inni autorzy dzieł z zakresu duchowości, uwypuklając m.in., że powołanie do doskonałości odnosi się do każdego chrześcijanina ${ }^{32}$. Ludwik z Granady podał w niej praktyczne wskazówki odnośnie życia modlitwy. Natomiast Przewodnik grzeszników, „z charakterystycznym dla autora mistrzostwem doktrynalnym połączonym z doskonałym stylem, traktuje o rozwoju życia chrześcijańskiego aż do osiągnięcia doskonałości"’33. Autor we wstępie do swojego dzieła, w następujących słowach wyjaśnił jego układ: „Podzielone ono będzie na dwie główne części: pierwsza wyjaśni powody skłaniające nas do praktykowania cnoty i nieocenione korzyści za nią idące; druga oznacza obowiązki, jakie cnota na nas nakłada i nauczy nas, jakimi sposobami ją nabyć. Aby poprowadzić człowieka do dobra, niezbędne są dwie rzeczy: pierwsza - wzbudzenie w nim szczerego pragnienia osiągnięcia tego celu, druga - wskazanie mu drogi, która do niego prowadzi. Ten - mówi pewien starożytny pisarz - kto pobudza do cnoty, a nie uczy zarazem, jak ją wykonywać, podobny jest do człowieka, który zapala lampę, a zapomina nalać oleju, by utrzymać w niej światło"34.

26 E. Ziemman, Naśladowanie Chrystusa, w: Encyklopedia Katolicka, t. 13, red. E. Gigilewicz, Lublin 2009, kol. 788-789.

27 Do 2009 r. przetłumaczono ją na ok. 100 języków i sięgnęła blisko 200 wydań, tamże, kol. 788.

28 Cyt. za: B. Calati, R. Grégoire, A. Blasucci, Historia duchowości, t. 4: Duchowość średniowiecza, Kraków 2005, s. 432.

29 R. Prejs, Robert Bellarmin, w: Encyklopedia Katolicka, t. 17, red. E. Gigilewicz, Lublin 2012, kol. 132-135.

30 Warto przypomnieć, że Ludwik z Granady 35 lat z 85-letniego życia poświęcił głoszeniu kazań oraz twórczości pisarskiej, zob. J. Aumann, Zarys historii duchowości, Kielce 1993, s. 236.

31 K. Panuś, Ludwik z Granady, w: Encyklopedia Katolicka, t. 11, Lublin 2006, red. E. Ziemann, kol. 178-179.

32 J.I. Saranyana, J.L. Illianes, Historia teologii, Kraków 1997, s. 250.

33 C. Brovetto, L. Mezzadri, F. Ferrario, P. Ricca, Historia duchowości, t. 5: Duchowość chrześcijańska czasów nowożytnych, Kraków 2005, s. 57-58.

${ }^{34}$ Ludwik z Granady, Przewodnik grzeszników, Warszawa 2002, s. 6. 
Z Niderlandów pochodził Dionizy Kartuz (I402/I403-I47I) autor wielu kazań i listów oraz ok. I50 dzieł teologicznych. Do tekstów z zakresu teologii moralnej i mistycznej możne zaliczyć Liber de quatuor hominis novissimis... ${ }^{35}$. Zawarte w nim rozważania, zostały przez kartuskiego mnicha podzielone na rozdziały traktujące o: śmierci, karach piekielnych, sądzie i szczęściu wiecznym. Jego myśl teologicznomoralna zaliczana jest do nurtu piśmiennictwa mistycznego i zestawiana z dziełami autorów tej miary co bł. Henryk Suzo (I295/97-I366), Jan Gerson (I363-I429) czy wspomniany wcześniej Tomasz a Kempis ${ }^{36}$. Jak stwierdza Jordan Aumann, „Wielką zasługą Dionizego Kartuza było zsyntetyzowanie całej wcześniejszej doktryny na temat życia duchowego i dokonanie wartościowania niektórych tez. Jego pisma są skierowane do wszystkich chrześcijan. W istocie układał on traktaty dla poszczególnych grup wiernych, jak biskupi, proboszczowie, osoby żonate, wdowy, żołnierze, kupcy i inni. Był głęboko przekonany o swoim obowiązku służenia ludowi Bożemu swoją twórczością"37.

Pod numerem I4. autor protokołu powizytacyjnego zapisał „Confessio Idiotae”. Bez wątpienia kryje się za tym dzieło autora z zakonu paulinów, Grzegorza Tereckiego (Terecjusz, 1596-I659 ${ }^{38}$. Napisał on Confessio et instructio idiotae sive modus excipiendi confessiones sacramentales rusticorum, puerorum, in peccatis inveteratorum ac ignorantium profectum in vita christiana, opublikowane po raz pierwszy w Krakowie w I655 r. Był to, bardzo przydatny w pracy duszpasterskiej na parafii, podręcznik słuchania spowiedzi i życia chrześcijańskiego. Autor przedstawił w nim m.in. podstawowe zagadnienia życia chrześcijańskiego, w tym jego cel i naturę, miłość Boga, cnoty i przeszkody, na jakie można się natknąć w dążeniu do doskonałości. Nadto autor sporo miejsca poświęcił obowiązkom spowiednika ${ }^{39}$.

Pozostała jeszcze jedna książka z księgozbioru parafialnego we Wrzawach. Jest nią dzieło De origine, situ et qualitate frisiae libri III... Zostało wydane w Kolonii w I588 r. Jego autorem jest holenderski historyk Cornelius Kempius (I5I6-I589), którego książka o Fryzji jest jedynym znanym dziełem tego autora ${ }^{40}$.

Tytułem podsumowania można powtórzyć przytoczoną już opinię, że księgozbiór parafialny we Wrzawach posiadał pod względem treściowym w połowie XVIII w. typowo duszpasterski charakter. Teksty Pisma Świętego, dzieła kaznodziejskie i teologiczne, przydatne w codziennej pracy na parafii, które zostały spisane przez autora protokołu powizytacyjnego, są tego czytelnym świadectwem. Jedynie książka Korneliusza Kempiusa nie mieści się we wskazanych obszarach. Jej obecność w badanym księgozbiorze można tłumaczyć prywatnymi zainteresowaniami czytelniczymi jednego z kapłanów. Być może była prezentem. Kwestia ta pozostaje nierozstrzygnięta.

Prezentowany poniżej spis książek we Wrzawach został opatrzony w przypisach aparatem krytycznym. Wynika to m.in. ze wskazówek zawartych w instrukcjach wydawniczych

\footnotetext{
35 A. Bazielich, Dionizy Kartuz, w: Encyklopedia Katolicka, t. 3, red. R. Łukaszyk, L. Bieńkowski, F. Gryglewicz, Lublin 1979, kol. 1339-1340.

36 S. Olejnik, Teologia moralna, t. 1: Wprowadzenie i idea wiodaca, Warszawa 1988, s. 90; M. Kanior, Historia monastycyzmu chrześcijańskiego, t. 2: Średniowiecze w Kościele zachodnim (od IX do XVI wieku), Kraków 2001, s. 197.

37 J. Aumann, Zarys historii duchowości, s. 207.

38 H. E. Wyczawski, Terecjusz Grzegorz, w: Stownik Polskich Teologów Katolickich, t. 4, s. 323-324.

39 S. Olejnik, Teologia ..., s. 119; P. Jemioł, Spowiedź ludzi prostych i kierownictwo duchowe wedlug „, Confessio et instructio idiotae” o. Grzegorza Tereckiego, „Studia Claramontana”, 2/1981, s. 248-275.

40 Repertorium van geschiedschrijvers in Nederland 1500-1800, red. E.O.G. Haitsma Mulier en G.A.C. van der Lem, Den Haag 1990, s. 218-2019.
} 
dotyczących edycji źródeł historycznych ${ }^{41}$. Jeśli pozycja występowała w Bibliografii polskiej Estreicherów, używano skrótu E oraz podawano numer tomu i stronę. Spis księgozbioru, który znajduje się w protokole powizytacyjnym, postanowiono przytoczyć jak najwierniej, dokonując uzupełnień w oczywistych przypadkach.

\section{Księgozbiór parafii we Wrzawach w 1748 r.}

- Wrzawy, k. I20.

- In libris:

- Biblia sacra ${ }^{42}$

- Kazania Lorencowicza 43

- Meditationes Buscvi44

- Kazania Stryjewicza ${ }^{45}$

- Kazania panegiryczne ${ }^{46}$

- Kempius $^{47}$

- Conciones Osorij quadrag[esimales $]^{48}$

- Pars Bibliarum ${ }^{49}$

- Didacus Nissenus de Sanctis ${ }^{50}$

- Thomas a Kempis ${ }^{5 \mathrm{I}}$

- Petri bussaei apercula ${ }^{52}$

- De aeterna felicitate Bellarminus ${ }^{53}$

- Granatensis ${ }^{54}$

${ }^{41}$ Instrukcja wydawnicza do źródel historycznych od połowy XVI do połowy XIX wieku, red. K. Lepszy, Wrocław 1953; Zasady wydawania tekstów staropolskich. Projekt, PAN, Instytut Badań Literackich, Wrocław 1955.

42 Nie można określić.

43 Lorencowicz Aleksander (1609-1675), jezuita, kaznodzieja, autor m.in. zbiorów: Kazania pogrzebne, Kalisz 1670, 20 oraz Kazania na niedziele całego roku.., Kalisz 1671, 20 (E, t. 21, s. 409).

44 Busaeus Joannes (1547-1611), jezuita, autor m.in. Enchiridion piarum meditationum in Dominicas ac festa totius anni. Nec non quadragesimae, quatuor-temporum, aliasque praecipuas ferias.., Antverpia 1723, 120 (E, t. 13 , s. 461. Tamże inne wydania).

45 Stryjewicz Sebastian Fabian (1621-1681), kanonik kolegiaty św. Floriana na Kleparzu, profesor Akademii Krakowskiej, komentator pism św. Tomasza z Akwinu, autor Kazania na święta uroczyste Pana Zbawiciela Naszego, Najświętszej Panny Mariej i Świętych Pańskich.., Kraków 1680, 40 (E, t. 29, s 349).

46 Nie można określić.

47 Kempius Cornelius (1516-1589), autor De origine, situ et qualitate frisiae libri III, Colonia 1588, 80 (Repertorium van geschiedschrijvers in Nederland 1500-1800, red. E.O.G. Haitsma Mulier en G.A.C. van der Lem, Den Haag 1990, s. 218-219).

48 Jan Osorius (1542-1549), jezuita, autor Conciones, cz. 1-5, Venetia 1596, 40 (Biblioteka Jagiellońska, sygn. Aug 11 156 II).

49 Nie można określić.

50 Didacus Nissenus (+1656), być może Opera omnia in tres tomos digesta, Kraków 1650, 40 (E, t. 23, s. 159-160).

51 Tomasz a Kempis (1380-1471), augustianin, autor traktatów religijnych, De imitatione Christi, było wiele wydań (polskie E, t. 31, s. 202-203).

52 Besseus Piotr (1567-1636), kaznodzieja francuski.

53 Bellarmin Robert (1542-1621) jezuita, teolog, autor De aeterna felicitate sanctorum libri quinque, Romae 1616, $8^{\circ}$ (R. Prejs, Robert Bellarmin, kol. 132-135).

54 Ludwik z Granady (1504-1588), dominikanin, autor m.in: Conciones de tempore, Lisbona 1574-1576, Conciones de sanctis, Lisbona 1578 r, O modlitwie i rozmyślaniu, Salamanka 1554, Przewodnik grzeszników czyli nauka dla wszystkich stanów o zacności i pożytkach cnót, Lisbona 1556/57 (K. Panuś, Ludwik z Granady, kol. 178-179). 
- Confessio Idiotae 55

- Dion carthus[iani] de novissimis ${ }^{56}$

\section{Book collection of the parish in Wrzawy in the light of the general visitation in 1748 Summary}

The article presents the parish library in Wrzawy in I748. Information about it was provided by the protocol of the general visitation of the archdeaconry of Zawichost in the diocese of Cracow, realized by the archdeacon of that time, Józef Cyprian Lange (+I757). The collection of 15 books had a typically pastoral character. Texts of the Holy Scriptures, homiletic works of Alexander Lorencowicz, Sebastian Stryjewicz, Jan Osorius, Didacus Nisenus theological-moral Jan Busaeus, Robert Bellarmine, Ludwik of Granada and ascetic Tomasz and Kempis, helped to work on the pulpit or in the confessional. Thus, although it was not a collection of books, it was varied in content.

Keywords: parish collections, Wrzawy, Cracow diocese, archdiocese of Zawichost

\section{BIBLIOGRAFIA}

Źródła rękopiśmienne

AKMK, sygn. AV 46, Archidiaconatus Zawichostensis, tres decanatus, videlicet Urzędoviensem, Opatoviensem et Zawichostensen, in quibus ecclesiae parochiales numerantur 45, complectens, sub felici regimine et auspiciis Cel. Principis R. D. Adreae Stanislai Kostka comitis in Załuskie Załuski, episcopi Cracoviensis, ducis Severiae, generali visitatione lustratus, per Cyprianum Joosephum Langi IUD, in ecclesia cathedrali Cracoviensi, archidiaconum Zawichostensem, canonicum Sandomieriensem, praepositum Rakoviensem anno I748. Wykorzystałem mikrofilm wizytacji przechowywany w ABMK, sygn. 33I7.

Opracowania

Aumann J., Zarys historii duchowości, Kielce 1993.

Barcik M., Sebastian Fabian Stryjewicz, w: Polski Słownik Biograficzny, t. 44, Kraków 2006-2007, s. 528-530.

Bazielich A., Dionizy Kartuz, w: Encyklopedia Katolicka, t. 3, red. R. Łukaszyk, L. Bieńkowski, F. Gryglewicz, Lublin I979, kol. I339-I340.

Besse Piotr, w: Podręczna Encyklopedia Kościelna, t. I-2, red. Z. Chełmicki, Warszawa I904, s. 279.

Brovetto C., Mezzadri L., Ferrario F., Ricca P., Historia duchowości, t. 5: Duchowość chrześcijańska czasów nowożytnych, Kraków 2005.

Budziło B., Gorzyce i Wrzawy. Zarys dziejów, Kraków 2000.

Budziło B., Wrzawy w świetle kronik, pamiętników i relacji, Wrzawy-Sandomierz 2008.

\footnotetext{
55 Terecjusz Grzegorz (1596-1659), paulin, moralista, teolog ascetyczny, autor Confessio et instructio idiotae sive modus excipiendi confessiones sacramentales rusticorum, puerorum, in peccatis inveteratorum ac ignorantium profectum in vita christiana, Cracovia 1655, 120 (E t. 31, s. 109), 2 wyd. 1686 w 80 (E, t. 31, s. 110).

56 Dionizy Kartuz (1402/03-1471), kartuz, teolog, mistyk, autor Liber de quatuor hominis novissimis (A. Bazielich, Dionizy Kartuz, kol. 1339-1340).
} 
Calati B., Grégoire R., Blasucci A., Historia duchowości, t. 4: Duchowość średniowiecza, Kraków 2005.

Czapnik M., Księgozbiór ks. Jana Bogusławskiego świadectwem zainteresowań cysterskiego kaznodzieiei i ttumacza, „Roczniki Biblioteczne”, 53/2009, S. I47-I72.

Estreicher K., Bibliografia polska, cz. 3, t. I2-34, Kraków I89I-I95I.

Instrukcja wydawnicza do źródet historycznych od połowy XVI do połowy XIX wieku, red. K. Lepszy, Wrocław 1953.

Jemioł P., Spowiedź ludzi prostych i kierownictwo duchowe wedtug , Confessio et instructio idiotae” o. Grzegorza Tereckiego, „Studia Claramontana”, 2/r98I, s. 248-275.

Kanior M., Historia monastycyzmu chrześcijańskiego, t. 2: Średniowiecze w Kościele zachodnim (od IX do XVI wieku), Kraków $200 \mathrm{I}$.

Kowalski W., Uposażenie parafii archidiakonatu sandomierskiego w XV-XVIII wieku, Kielce 1998.

Krzysztofik M., Biblia w kazaniach pogrzebnych Aleksandra Lorencowicza (I670) - płaszczyzna obecności, funkcje nawiazania, „Zeszyty Naukowe Uniwersytetu Rzeszowskiego”, Seria Filologiczna, Zeszyt 65/20I0, Historia literatury 5, s. 62-78.

Krzysztofik M., Siedemnastowieczna refleksja o rolach kobiety i mężczyzny w matżeństwie (na podstawie kazań pogrzebowych), „Res gestae. Czasopismo historyczne”, 20I6, nr 3, s. 5-I8.

Kumor B., Dzieje diecezji krakowskiej do roku I795, t. 4, Kraków 2002.

Litak S., Kościół łaciński w Rzeczypospolitej około 1772 roku. Struktury organizacyjne, Lublin 1996.

Ludwik z Granady, Przewodnik grzeszników, Warszawa 2002.

Moskal T., Biblioteki parafialne $w$ archidiakonacie sandomierskim $w$ XVIII wieku, Sandomierz 2005.

Nitecki P., Biskupi Kościoła w Polsce w latach 965-1999. Słownik biograficzny, Warszawa 2000.

Olejnik S., Teologia moralna, t. I: Wprowadzenie i idea wiodaca, Warszawa 1988.

Ozorowski E., Gutowski Walerian Wojciech, w: Słownik Polskich Pisarzy Franciszkańskich, red. H. E. Wyczawski, Warszawa I98I, s. I68-I69.

Ozorowski E., Stryjewicz Sebastian Fabian, w: Słownik Polskich Teologów Katolickich, t. 4, red. H. E. Wyczawski, Warszawa I983, s. 2I8-2I9.

Panuś K., Lorencowicz Aleksander, w: Encyklopedia Katolicka, t. Io, red. E. Ziemann, Lublin 2004, kol. 1396.

Panuś K., Ludwik z Granady, w: Encyklopedia Katolicka, t. II, red. E. Ziemann, Lublin 2006, kol. I78-I79.

Panuś K., Zarys historii kaznodziejstwa w Kościele katolickim, t. 2, cz. I: Kaznodziejstwo w Polsce. Od Średniowiecza do Baroku, Kraków $200 \mathrm{I}$.

Pawlak W., ,, O pewnym sposobie naszych literatów, że przy niewielkim czytaniu mogą się tatwo wielkimi erudytami pokazać”. Kompendia jako źródło erudycji humanistycznej, w: Staropolskie kompendia wiedzy, red. I. M. Dacka-Górzyńska, J. Partyka, Warszawa 2009, s. 45-72.

Pawlak W., Praedicator urbanus - Walerian Gutowski OFMConv., w: Wielcy kaznodzieje Krakowa. Studia in honorem prof. Eduardi Staniek, Kraków 2006, s. 19I-226.

Prarat W., Parafia Wrzawy. Zarys dziejów, Wrzawy-Sandomierz 2008. 
Prarat W., Wrzawy. Szkice z dziejów wsi, Wrzawy-Sandomierz 200 I.

Prejs R., Robert Bellarmin, w: Encyklopedia Katolicka, t. I7, red. E. Gigilewicz, Lublin 20I2, kol. I32-I35.

Prejs R., Tomasz a Kempis, w: Encyklopedia Katolicka, t. I9, red. E. Gigilewicz, Lublin 2013, kol. 870-87I.

Rawski J., Wybrane zagadnienia dotyczace administracji kościelnej w widłach Wisty $i$ Sanu, Tarnobrzeg 1997.

Repertorium van geschiedschrijvers in Nederland I500-I80o, red. E.O.G. Haitsma Mulier en G.A.C. van der Lem, Den Haag 1990.

Saranyana J.I., Illianes J.L., Historia teologii, Kraków 1997.

Sas J., Aleksander Lorencowicz. Studium z epoki panegirycznej, „Przegląd Powszechny”, 39/I893, s. 8I-I02, I85-209, 363-387.

Szady J., Księgozbiory parafialne w prepozyturze wiślickiej w II połowie XVIII wieku, Lublin 2008.

Szczepaniak J., Duchowieństwo diecezji krakowskiej w XVIII wieku. Studium prozopograficzne, Kraków 20 Io.

Szczepaniak J., Katalog duchowieństwa diecezjalnego zestawiony na podstawie krakowskich ksiąg święceń (I646-I789), A-I, Kraków 2008.

Szczepaniak J., Spis prepozytów i plebanów diecezji krakowskiej (XVIII w.), Kraków 2008.

Szteinke A., Gutowski Bernard, w: Stownik Polskich Teologów Katolickich, t. I, red. H. E. Wyczawski, Warszawa I983, s. 6II-6I2.

Szudrowicz A., Biblioteka klasztoru karmelitów w Kcyni, „Archiwa Biblioteki i Muzea Kościelne", 78/2002, s. 234-274.

Wiśniewski J., Katalog prałatów i kanoników sandomierskich od II86 do I929 r., tudzież sesje kapituły sandomierskiej od I58I do I866 r., Radom I928.

Wyczawski H. E., Terecjusz Grzegorz, w: Słownik Polskich Teologów Katolickich, t. 4, red. H. E. Wyczawski, Warszawa I983, s. 323-324.

Zasady wydawania tekstów staropolskich. Projekt, PAN, Instytut Badań Literackich, Wrocław 1955.

Ziemman E., Naśladowanie Chrystusa, w: Encyklopedia Katolicka, t. I3, red. E. Gigilewicz, Lublin 2009, kol. 788-789.

Zwiercan A., Gutowski Wojciech, w: Encyklopedia Katolicka, t. 6, red. J. Walkusz, Lublin I993, kol. 4IO. 